\title{
Survey Study of Psychological Conditions of Martial Arts Athletes
}

\author{
Rajip Mustafillah Rusdiyanto* \\ Departemen Pendidikan Jasmani \\ Universitas Majalengka \\ Majalengka, Indonesia \\ *rajipmustafillahr@gmail.com
}

\author{
Herman Subarjah, Amung Ma'mun, Mulyana Mulyana \\ Departemen Pendidikan Jasmani \\ Universitas Pendidikan Indonesia \\ Bandung, Indonesia
}

\begin{abstract}
This research is a survey study on the pencak silat athletes' psychological condition. The purpose of this study will provide a psychological description of the athletes. This study is expected to maximize the achievements of martial arts athletes by providing an overview of the psychological requirements of martial arts athletes as a basis for selection. The method used in this study was a cross-sectional survey study. Questionnaires were distributed to 21 pencak silat national athletes who participated in the 2018 Asian Games event. The instrument used to collect data was the Athletic Coping Skills Inventory (ACSI) questionnaire which included Coping with Adversity aspects, Peaking Under Pressure, Goal Setting / Mental Preparation, Freedom from Worry, Confidence and Achievement Motivation, and Coach ability. The questionnaire aims to provide an overview of the athletes from psychology perspective. The results revealed that the athletes in general are able to face the difficulties they face calmly, are able to work optimally under pressure, has an exercise plan in achieving goals, has a strong mentality, is able to focus on one goal, has high motivation in achieving goals and practicing is an obligation to achieve. To conclude, this study provides an overview of the required psychological character of a martial arts athlete.
\end{abstract}

Keywords—sport psychology; pencak silat; psychological conditions; mental

\section{INTRODUCTION}

Pencak silat is a native Indonesian culture that is spread throughout the country. At first, silat was used by the people during the colonial period to defend themselves, now it gradually developed into a culture that was used for ceremonies and entertainment [1]. Pencak silat is an authentic Indonesian martial art, which is spread throughout the region. Pencak silat was competed in 1989 and the 1982 Pencak Silat World Championship [1]. Pencak silat is divided into three contexts, namely martial arts which are exhibited through the attractiveness of movement and rhythm, pencak silat as a sport, and pencak silat as a tool for self-defense [2]. In the modern era, pencak silat developed into an achievement sport that competed in rival categories and art categories. For the art category it consists of single numbers, team numbers, and double numbers.

Pencak silat includes a combination of aerobic and anaerobic exercises, where an athlete must be able to survive fatigue within three minutes [1]. The characteristics of pencak silat are similar to Taekwondo and Boxer sports. The use of limbs and arms as a means to get points in a match [3], both have a contribution in supporting the athletic abilities of athletes [4]. Techniques, strategies, psychological and physical conditions become a unity in supporting athletes' achievements [5]. Pencak silat is a sport that has the characteristics of high anaerobic and aerobic metabolic responses [1] this does not provide conclusions and requires further detailed research. The physiological response of male martial arts athletes is Vo2max 52.1, grip strength 435 , leg explosive power 59.9 while for girls Vo2max 43.1, grip strength 271, explosive power of legs 40.8 [1]. the Vo2max level of martial arts athletes, both female and male, is the lowest level compared to taekwondo and judo martial artists [1]. The explosive power of limbs in Pencak Silat athletes is better than that of judo and taekwondo athletes [1]. High intensity exercise for the legs is needed. The characteristics of the Kata category in karate are almost the same, the assessment includes; techniques, rhythm, strength, short expressive movements and isometric muscle contractions are performed when the technique is complete [6]. Perfect physical condition will have a positive impact during a competition. The fighter will compete constantly from the initial round until the final round. Perfect physical condition will make the fighter sidestep fatigue and injury [6]. So that the athletes will have the opportunity to obtain optimal achievements. Achievement is the result of several inseparable and interdependent supporting components [7].

Physical conditions are not the only supporting athlete's best performance. Psychological aspects are very important for the best performance of Pencak Silat athletes, this is a determinant of victory [8,9]. Anxiety plays an important role for every athlete physical contact. A fighter will be easier to join a match with perfect physical condition compared to sufficient physical condition [10]. One that can raise anxiety is that athletes do not have realistic goals with their abilities [9] [8]. Anxiety is the impact of the athlete's inability to master skills and physical conditions, so this will have an impact on the emergence of anxiety. Anxiety is closely related to the athlete's mentality in facing a big match. In other words, imperfect physical conditions will be concealed with good psychological aspects [11]. Therefore, this study tries to survey Indonesian athletes who won the championship to see whether psychological factors influence their achievements. 


\section{METHOD}

This study used a cross-sectional survey study. The sample used was 21 pencak silat national athletes consisting of match and art categories. The instruments used are the athletic coping skills inventory (ACSI) [11]. The instrument aims to provide an overview of athletes' competitiveness. There are 7 aspects, including; Coping With Adversity, Peaking Under Pressure, Goal Setting / Mental Preparation, Freedom from Worry, Confidence and Achievement Motivation, and Coach ability [11]. The questionnaire consists of 28 items with the following scales; almost never $=0$, sometimes $=1$, often $=2$, and almost always $=3$. The results of the study are described in description.

\section{RESULTS AND DISCUSSION}

The survey results illustrate that all athletes are able to control their emotions regardless of how bad things are. As things get worse, these athletes are able to give suggestions for staying calm, and that really helps them.

TABLE I. RESUlTS OF THE ATHLETIC COPING SKILL INVENTORY

\begin{tabular}{|l|l|}
\hline & Average Score \\
\hline Goal setting/mental preparation & 7,571429 \\
\hline Confidence and achievement motivation & 7,809524 \\
\hline Coachability & 8,190476 \\
\hline Concentration & 6,904762 \\
\hline Coping with adversity & 6,190476 \\
\hline Peaking under pressure & 6 \\
\hline Freedome from worry & 7,428571 \\
\hline
\end{tabular}

When the athlete feels tense, they are able to overcome the tension and ease it. These athletes are able to think positively and readily during competition without thinking about how bad things are. Almost all athletes assume that pressing situations are obstacles that they can welcome and enjoy. However, not all athletes can play better under pressure, but they can handle it. Mistakes often occur when the athletes experiences pressure, but does not make it a weakness.

Every athlete has very specific training goals that guide them in doing everything and planning in order to achieve all their goals.

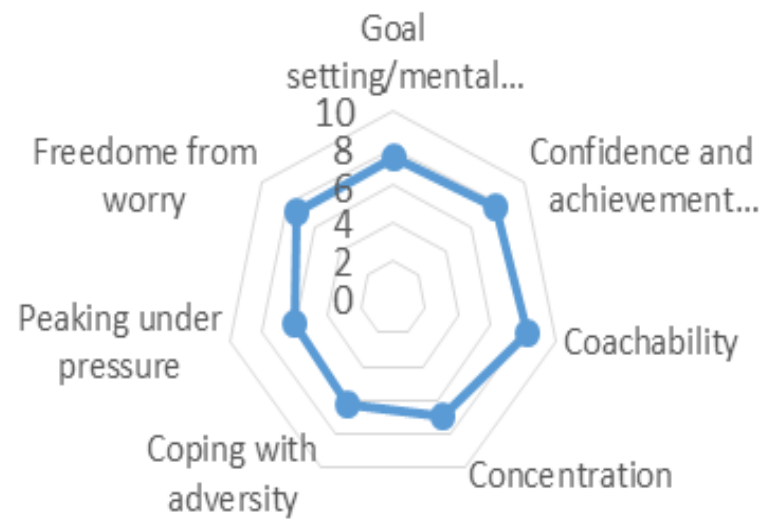

Athletes are able to set goals to achieve better performance in each exercise. Every athlete has a game plan in mind long before the game starts. Every athlete can control an unexpected situation well. Every athlete can focus his attention and avoid interference. It's easy for athletes to keep distracting themselves from things that can interfere with their focus. Every athlete is able to easily direct his attention and stay focused on one goal. When competing, athletes do not have the fear of making mistakes and fail to pass them, because they enjoy the match. Almost every athlete, does not put pressure on him by worrying about his playing during the match.

Every athlete does not dwell on and imagine what will happen if it fails, regardless of what others think of their appearance. Athlete's confidence increases when they play well. Athletes are able to bring out all their talents and abilities. When they fail to achieve their goals, they continue to strive to get back up. All athletes do not need to be forced to practice. Athletes always give all their abilities.

The results showed that these athletes had fairly good psychological conditions. This is a determining factor for them to achieve their best performance. They are able to face difficulties, able to work under pressure. The athlete's mentality is a performance supporter. The athlete's mentality includes the ability to concentrate, to survive, to motivate success, to expect positive results, to be able to control emotions, and to understand the sports context [12].

The most striking results from the average table 3.1 are concentration. This gives an illustration that athletes are able to construct to achieve their goals. This is evidenced by the achievements of pencak silat athletes at the 2018 Asian Games in Jakarta-Palembang, with 14 gold medals and 1 bronze medal. The athletes are able to focus and construct during the competition. Self-management in terms of psychology is a very important one, good mental condition enables the athlete to withstand any pressure him during the training process or during the competition [13]. Goal setting / mental preparation plays an important role in increasing athlete's performance [14]. Both theories have been able to explain the psychological importance s in supporting the athletes' performance.

\section{CONCLUSION}

The results showed that psychological factors have a major contribution to the athletes' performance of athletes. However, the investigation of other variables are also needed to confirm this result in order to give more wide-ranging point of view for the observed case. In addition, this study merely surveyed the condition of Indonesian Pencak Silat athletes so that further investigation with different context and subject research is essential to provide better understanding on the factors affecting athletes' performance.

\section{REFERENCES}

[1] A. R. Aziz, B. Tan, and K. C. Teh, "Physiological responses during matches and profile of elite pencak silat exponents," J. Sport. Sci. Med., vol. 1 , no. 4 , pp. $147-155,2002$

Fig. 1. ACSI indicator percentage. 
[2] M. Kartomi, "Traditional and modern forms of pencak silat in Indonesia: The suku mamak in Riau," Musicol. Aust., vol. 33, no. 1, pp. 47-68, 2011.

[3] S. Chiodo, A. Tessitore, C. Lupo, A. Ammendolia, C. Cortis, and L. Capranica, "Effects of official youth taekwondo competitions on jump and strength performance," Eur. J. Sport Sci., vol. 12, no. 2, pp. 113 $120,2012$.

[4] J. Heller, T. Perič, R. Dlouhá, E. Kohlíková, J. Melichna, and H. Nováková, "Physiological profiles of male and female taekwon-do (ITF) black belts," J. Sports Sci., vol. 16, no. 3, pp. 243-249, 1998.

[5] K. A. Matsushigue, K. Hartmann, and E. Franchini, "Taekwondo: Physiological Responses and Match Analysis," J. Strength Cond. Res., vol. 23, no. 4, pp. 1112-1117, Jul. 2009.

[6] C. A. Bridge, J. F. S. Santos, H. Chaabène, W. Pieter, and E. Franchini, "Physical and physiological profile of taekwondo athletes," Sport. Med., vol. 44, no. 6, pp. 713-733, 2014.

[7] B. Ghorbanzadeh, S. Mündroğlu, C. Akalan, M. R. Khodadadi, S. Kdrazci, and M. Şahdn, "Determination of Taekwondo National Team Selection Criterions by Measuring Physical and Physiological Parameters.," Ann. Biol. Res., vol. 2, no. 6, pp. 184-197, 2011.

[8] J. Graydon, "Stress and anxiety in sport," Psychologist, vol. 15, no. 8, pp. 408-410, 2002.
[9] Martin and Gill, "The Relationships Among Competitive Orientation , sport confidence, self efficacy, anxiety and performance," J. Sport Exerc. Psychol., vol. 13, pp. 149-160, 1991.

[10] A. E. Hardman, C. Williams, and S. A. Wootton, "The influence of short-term endurance training on maximum oxygen uptake, submaximum endurance and the ability to perform brief, maximal exercise,” J. Sports Sci., vol. 4, no. 2, pp. 109-116, 1986.

[11] R. E. Smith, R. W. Schutz, F. L. Smoll, and J. T. Ptacek, "Developmen and Validation of a Multidimensional Measure of Sport-Specific Psychological Skills: The Athletic Coping Skills Inventory-28,” J. Sport Exerc. Psychol., vol. 17, no. 4, pp. 379-398, 1995.

[12] S. Gordon and D. F. Gucciardi, “A strengths-based approach to coaching mental toughness,” J. Sport Psychol. Action, vol. 2, no. 3, pp. 143-155, 2011.

[13] M. Sarkar, D. Fletcher, M. Sarkar, and D. Fletcher, "Psychological resilience in sport performers: a review of stressors and protective factors protective factors," no. June, pp. 37-41, 2014.

[14] J. P. Whelan, C. C. Epkins, and A. W. Meyers, "Arousal interventions for athletic performance: Influence of mental preparation and competitive experience AROUSAL INTERVENTIONS FOR ATHLETIC PERFORMANCE: INFLUENCE OF MENTAL," no. December 2014, pp. 37-41. 